\title{
Influence of Dietary Supplementation of Coated Sodium Butyrate and/or Synbiotic on Growth Performances, Caecal Fermentation, Intestinal Morphometry and Metabolic Profile of Growing Rabbits
}

\author{
A. Hassanin ${ }^{1}$, M. A. Tony ${ }^{2}$, F. A. R. Sawiress ${ }^{3}$, M. A. Abdl-Rahman ${ }^{3} \&$ Sohair Y. Saleh $^{3}$ \\ ${ }^{1}$ Department of Cytology and Histology, Faculty of Veterinary Medicine, University of Sadat City, Meonofya, \\ Egypt \\ ${ }^{2}$ Department of Nutrition and Clinical Nutrition, Faculty of Veterinary Medicine, Cairo University, Giza, Egypt \\ ${ }^{3}$ Department of Physiology, Faculty of Veterinary Medicine, Cairo University, Giza, Egypt \\ Correspondence: Sohair Y. Saleh, Department of Physiology, Faculty of Veterinary Medicine, Cairo University, \\ Giza-12211, Egypt. Tel: 202-3338-6209. E-mail: sohair_saleh@hotmail.com
}

Received: November 26, 2014 Accepted: December 29, 2014 Online Published: January 15, 2015

doi:10.5539/jas.v7n2p180 URL: http://dx.doi.org/10.5539/jas.v7n2p180

\begin{abstract}
The aim of the present experiment was to study the synergistic effects of dietary supplementation with coated slow released sodium butyrate $\left(\mathrm{CM} 3000^{\circledR}\right)$ and a commercial synbiotic (Poultry-Star $\left.{ }^{\circledR}\right)$ on the productive performance and intestinal morphometry of the growing rabbits. Thirty two apparently healthy male New Zealand rabbits with average body weight of $544 \pm 9 \mathrm{~g}$ were divided randomly into four dietary treatments at weaning ( $28^{\text {th }}$ day of age). The control group (C) was fed on standard basal diet with no supplementation. Rabbits in the second group (T1) received the same basal diet supplemented with CM3000 ${ }^{\circledR} 500 \mathrm{~g} /$ ton feed. Animals in the third group (T2) consumed the basal diet containing Poultry-Star ${ }^{\mathbb{B}} 500 \mathrm{~g} /$ ton feed. Rabbits in the fourth group (T3) were fed on the basal diet enriched with mixture of CM $3000^{\circledR}$ and Poultry-Star ${ }^{\circledR}, 250 \mathrm{~g} /$ ton feed $^{-1}$ for each. Feed and water were offered ad-libitum during 70 days experimental period. Body weight and feed consumption were recorded biweekly to calculate body weight gain and feed conversion. At the end of the experimental period blood and caecal content samples were collected from all animals. Duodinal tissue samples were collected for histomorphometry. The results revealed that additives used improved significantly live body weight compared to the control group. Rabbits in T3 group showed the highest body weight gain. In addition, supplementation of the basal diet with a mixture of additives revealed significant increase of feed intake. The blood urea level was reduced significantly in bucks of T1. The rabbits in T3 group recorded the highest level of blood glucose. Caecal pH revealed a significant decrease in $\mathrm{T} 1$ and $\mathrm{T} 3$. The mixture of additives has positive results on the intestinal morphometry. Coated butyrate and synbiotic are capable of improving performance, enhancing intestinal health.
\end{abstract}

Keywords: rabbits, sodium butyrate, synbiotic, zootechnical performance, intestinal morphology

\section{Introduction}

Rabbit meat for its dietetic and nutritional characteristics is accepted by the consumer as a product of high quality meat. Rabbit meat is lean and its lipids are highly unsaturated (60\% of the total fatty acids), rich in protein (20-21\%) with high biological values, very low in cholesterol and sodium and rich in potassium and magnesium (Dalle Zotte, 2000). Under intensive production conditions (high genetic makeup breeds, high density of breeding unit, developing feeding mills, early weaning, etc), multi-factorial stressors (environmental, nutritional, managerial, etc) affects and suppress the health and production of all rabbit breeds. Improvement of the rabbit health and productive performance are very important to maximize the production at low cost. Recently using of growth promoters and feed additives to maintain rabbit health and maximize economics of rabbit meat production has increased.

Short review of European Union (2003) recorded that the rabbit's gut microflora are the key factors to maintain rabbit's health, zootechnical performance and reproduction. This review pay attention to feed additives that favour better rabbit gut microbiota with special emphasize on their effects on growth performance and health status as safe, reliable and efficacious alternatives to antibiotics in rabbit nutrition. 
It is reported that butyrate derived from the fermentation of non-starch polysaccharides is considered to be important for normal development of epithelial cells with improved gastrointestinal health and reduced incidence of enteric diseases (Bron et al., 2002). Sakata (1987) reported that infusion of butyrate into fistulated rats increased the proliferation of crypt cells in both the small and large intestines. Sharma et al. (1995) suggested that the effect on crypt cell growth might reflect changes in the gut microflora, which is known to be a major modulator of epithelial cell activity. It has been demonstrated that short chain organic acids produced from fibre fermentation can inhibit the growth of bacteria of the group Enterobacteriaceae. Hume et al. (1993) showed that butyric acid has a higher diffusion coefficient through the pathogenic cell wall than other acids with shorter chains, which allows it to pass through the bacterial membrane more easily. Furthermore, in a recent work by Sunkara et al. (2011), the hypothesis that sodium butyrate is capable of inducing host defence peptides (HDPs) and enhancing disease resistance. Host defence peptides are natural broad spectrum antimicrobials and an important first line of defence in almost all forms of life.

Unfortunately, the natural levels of butyrate from fibre fermentation are quite low in the intestine and caeca (van der Wielen, 2000). Moreover, uncoated butyrate feed additive is immediately absorbed in the first part of the digestive tract before reaching the large intestine. In order to exert the influence in the large intestine, dietary butyrate should slowly be released over the gastrointestinal tract (Hu \& Guo, 2007).

Probiotics, prebiotics and synbiotics have proven to be effective in reducing mortality in domestic animals (Collier et al., 2010) by maintaining the microbial balance in the digestive tract and reducing potentially pathogenic bacteria (Corcionivoschi et al., 2010). Several strains of probiotic bacteria and yeast have reduced mortality in various species of animals (Collier et al., 2010; Peret et al., 1998), and beneficial effects are more pronounced in conditions of stress or in herds with high mortality (Ewing, 2008). However, few studies have evaluated the effectiveness of synbiotics in rabbits.

Low information is available regarding the effect of adding coated or slowly released butyrate products with or without combination with synbiotic in rabbit diets. Based on this concept, the goal of the present study was to investigate the synergistic effects of dietary supplementation with coated slow released sodium butyrate $\left(\mathrm{CM} 3000^{\circledR}\right)$ and a commercial synbiotic $\left(\right.$ Poultry-Star $\left.^{\circledR}\right)$ on the productive performance and intestinal morphometry of the postweaning growing rabbits.

\section{Materials and Methods}

\subsection{Feed Additives Used}

1) $\mathrm{CM} 3000^{\circledR}$ is a commercial $30 \%$ microencapsulated sodium butyrate. $\mathrm{CM} 3000^{\circledR}$ keeps releasing slowly and continuously in both small and large intestine. $\mathrm{CM} 3000^{\circledR}$ is manufactured by Hangzhou King Techina Feed Co., Ltd, China.

2) Poultry-Star ${ }^{\circledR}$ is a microencapsulated synbiotic product for feed application. Poultry-Star ${ }^{\circledR}$ contains multi-species probiotic microorganisms (Enterococcus faecium, Pediococcus acidilactici, Bifidobacterium animalis, Lactobacillus reuteri and Lactobacillus salivarius) combined with prebiotic fructo-oligosaccharide (FOS). Poultry-Star ${ }^{\circledR}$ produced by BIOMIN America, Inc, USA.

\subsection{Experimental Animals, Housing and Diets}

Thirty two apparent healthy, weaned male New Zealand white bucks 35 day age and average body weight of 544 $\pm 9 \mathrm{~g}$ were used. The rabbits were weighed individually and randomly allocated to four dietary treatments $(8$ animals/group). The rabbits were housed individually in commercial cages $(55 \times 60 \times 34 \mathrm{~cm})$, equipped with automatic drinkers and j-feeders. Daily lighting regime was 10-12 hour photoperiod/day through both natural and fluorescent lighting. The study was conducted in the experimental rabbitry of Physiology Department, Faculty of Veterinary Medicine Cairo University, Egypt.

Basal diet was formulated and analysed to cover the nutrient requirements of growing rabbits as recommended in NRC (1977) (Table 1).

Feed and water were provided ad-libitum for 70 days experimental period. Rabbits in the first group were offered non-supplemented basal diet and served as a control group (C). Animals in the second group were reared on the basal diet supplemented with $\mathrm{CM} 3000^{\circledR} 500 \mathrm{~g} /$ ton feed (T1). Rabbits in the third group consumed the basal diet containing Poultry-Star ${ }^{\circledR} 500 \mathrm{~g} /$ ton feed (T2). While rabbits in the fourth group were fed on the basal diet enriched with both $\mathrm{CM} 3000^{\circledR}$ and Poultry-Star ${ }^{\circledR}, 250 \mathrm{~g} /$ ton feed for each additive (T3). Individual body weights for all animals as well as the rest of feeds were recorded biweekly. Body weight gain and feed conversion were calculated. 
Table 1. Composition percentage, calculated nutrients profile and chemical analyses of the basal diet

\begin{tabular}{llll}
\hline Ingredients (\%) & $\%$ & Calculated analysis $(\%)^{* *}$ & \\
& & Crude protein & 17.5 \\
& & Crude fiber & 14.0 \\
Berseem hay & 30.0 & Ether extract & 2.7 \\
Barley grain & 21.0 & Nitrogen free extract & 56.4 \\
Yellow corn & 5.0 & Digestible energy $(\mathrm{kcal} / \mathrm{kg})$ & 2600 \\
Wheat bran & 21.1 & Chemical analysis $(\%)^{* *}$ & \\
Soybean meal & 17.5 & DM & 90.1 \\
Molasses & 3.0 & Moisture & 9.9 \\
CaCl & & Crude protein & 17.7 \\
NaCl & 1.5 & Crude fiber & 13.8 \\
Vit.\&Min. Premix & 0.4 & Total ash & 3.5 \\
DL-Methionine & 0.3 & Ether extract & 2.3 \\
& 0.2 & Nitrogen free extract & 52.8 \\
\hline
\end{tabular}

Note. ${ }^{*}$ The Rabbit's vitamin and mineral premix/kg contained the following IU/g for vitamins or minerals: A-4,000,000, D3-5000,000, E-16,7 g, K-0.67 g, B1-0.67 g, B2-2 g, B6-0.67 g, B12-0.004 g, B5-16.7 g, Pantothinc acid-6.67 g, Biotein-0.07 g, Folic acid-1.67 g, Choline chloride-400 g, Zn-23.3 g, Mn-10 g, Fe-25 g, Cu-1.67 g, I-0.25 g, Se-0.033 g, and Mg-133.4 g (Rabbit premix); ${ }^{* *}$ Based on NRC (1977); ${ }^{* * *}$ According to AOAC (1999).

\subsection{Blood and Caecal Content Samples}

Blood samples were collected at the end of the experimental period (at 105 days of age) from the ear vein of all animals at the morning before accesses to feed and water. Citrated plasma (in a ratio of 1 volume sodium citrate (3.8\%): 9 volumes blood) Serum was obtained for determination of certain haematological metabolic parameters namely, glucose (Trinder, 1969), triglycerides (Wahlefeld, 1974), total cholesterol (Allian, 1974), total protein (Henry, 1964), albumen and urea (Fawcett \& Scott, 1960).

Caecal content samples were collected at the end of the experimental period post slaughtering for determination of caecal fermentation pattern namely, pH, total short chain fatty acids (Eadie et al., 1967), individual volatile fatty acids (Samuel et al., 1997) and ammonia concentration (Chaney \& Marbach, 1962; Abdl-Rahman et al., 2010).

\subsection{Histological Investigation of the Intestinal Wall}

At the end of the experimental period rabbits were slaughtered. Tissue samples were collected from the duodenum, $10 \mathrm{~cm}$ from the pyloric junction, flushed with physiological saline and fixed in $10 \%$ buffered neutral formaldehyde solution for $48 \mathrm{hr}$, dehydrated in a graded series of ethanol, cleared in xylene and embedded in paraffin. Cross sections $5 \mu \mathrm{m}$ thickness were cut and mounted on slides and stained with hematoxylin and eosin.

\subsection{Histomorphometry}

Villus height was measured by averaging the height of 10 intact villi, from the tip of the villus to the end of the crypt depth. The duodenal gland lenght was determined as the distance between the lamina muscularis mucosa and the tunica musuclaris externa, while the villus width was measured as the distance beween the eoithelium at the middle of the villus. Morphological indices were measured using image processing and analysis system (Version 1, Leica Imaging System Ltd., Cambridge, UK).

\subsection{Statistical Analysis}

All data were statistically analysed using IBM SPSS ${ }^{\circledR}$ version 19 software for personal computer (2010). Means were compared by one way ANOVA $(p<0.05)$ using Post Hoc test according to Snedecor and Cochran $(1980)$. 


\section{Results}

\subsection{Zootechnical Performance}

The live body weight and body weight gain in the treated groups were significantly improved $(p<0.05)$ in comparison with the control group (Tables 2 and 3).

Table 2. Effects of sodium butyrate and/or synbiotic on live body weight of growing male rabbit ( $\mathrm{g} / \mathrm{rabbit}$ ) raised to70 days of age (means \pm SE)

\begin{tabular}{lllll}
\hline Age (day) & Control & $\begin{array}{l}\text { T1 } \\
\text { Sod. butyrate }\end{array}$ & $\begin{array}{l}\text { T2 } \\
\text { Synbiotic }\end{array}$ & $\begin{array}{l}\text { T3 } \\
\text { Mixture }\end{array}$ \\
\hline 35 & $544.37 \pm 6.3^{\mathrm{a}}$ & $544.38 \pm 6.3^{\mathrm{a}}$ & $544.37 \pm 6.3^{\mathrm{a}}$ & $539.38 \pm 8.6^{\mathrm{a}}$ \\
49 & $656.25 \pm 22.0^{\mathrm{a}}$ & $800.00 \pm 23.1^{\mathrm{bc}}$ & $768.75 \pm 33.9^{\mathrm{b}}$ & $850.00 \pm 16.3^{\mathrm{c}}$ \\
63 & $875.00 \pm 19.4^{\mathrm{a}}$ & $1325.00 \pm 21.1^{\mathrm{c}}$ & $1181.25 \pm 16.2^{\mathrm{b}}$ & $1378.12 \pm 24.7^{\mathrm{c}}$ \\
77 & $1387.50 \pm 18.2^{\mathrm{a}}$ & $1643.75 \pm 17.5^{\mathrm{c}}$ & $1568.75 \pm 24.8^{\mathrm{b}}$ & $1708.75 \pm 19.4^{\mathrm{d}}$ \\
91 & $1671.87 \pm 17.5^{\mathrm{a}}$ & $2030.62 \pm 17.5^{\mathrm{b}}$ & $2000.00 \pm 17.5^{\mathrm{b}}$ & $2184.37 \pm 17.5^{\mathrm{c}}$ \\
105 & $2011.87 \pm 20.6^{\mathrm{a}}$ & $2350.00 \pm 13.3^{\mathrm{c}}$ & $2300.00 \pm 13.4^{\mathrm{b}}$ & $2468.75 \pm 13.1^{\mathrm{d}}$ \\
\hline
\end{tabular}

Note. Different superscripts within a row indicate a significant treatment effect $(p<0.05)$.

Table 3. Effects of sodium butyrate and/or synbiotic on body weight gain of growing male rabbit ( $\mathrm{g} / \mathrm{rabbit}$ ) raised to70 days of age (means \pm SE)

\begin{tabular}{lllll}
\hline Age (day) & Control & $\begin{array}{l}\text { T1 } \\
\text { Sod. butyrate }\end{array}$ & $\begin{array}{l}\text { T2 } \\
\text { Synbiotic }\end{array}$ & $\begin{array}{l}\text { T3 } \\
\text { Mixture }\end{array}$ \\
\hline 49 & $111.88 \pm 4.5^{\mathrm{a}}$ & $255.62 \pm 4.2^{\mathrm{b}}$ & $224.38 \pm 3.3^{\mathrm{b}}$ & $310.62 \pm 5.2^{\mathrm{c}}$ \\
63 & $218.75 \pm 4.7^{\mathrm{a}}$ & $525.00 \pm 7.5^{\mathrm{c}}$ & $412.50 \pm 9.8^{\mathrm{b}}$ & $528.12 \pm 6.3^{\mathrm{c}}$ \\
77 & $512.50 \pm 12.3^{\mathrm{c}}$ & $318.75 \pm 11.2^{\mathrm{a}}$ & $387.50 \pm 13.4^{\mathrm{b}}$ & $330.63 \pm 16.5^{\mathrm{a}}$ \\
91 & $284.37 \pm 17.3^{\mathrm{a}}$ & $386.87 \pm 19.5^{\mathrm{c}}$ & $431.25 \pm 20.0^{\mathrm{b}}$ & $475.62 \pm 18.2^{\mathrm{c}}$ \\
105 & $340.00 \pm 18.1^{\mathrm{c}}$ & $319.38 \pm 15.6^{\mathrm{b}}$ & $300.00 \pm 17.8^{\mathrm{a}}$ & $284.38 \pm 18.6^{\mathrm{a}}$ \\
Total & $1467.50 \pm 21.8^{\mathrm{a}}$ & $1805.62 \pm 18.3^{\mathrm{c}}$ & $1755.63 \pm 17.5^{\mathrm{b}}$ & $1929.37 \pm 19.3^{\mathrm{d}}$ \\
\hline
\end{tabular}

Note. Different superscripts within a row indicate a significant treatment effect $(p<0.05)$.

Live body weight showed significant differences $(p<0.05)$ at the end of the experiment in the following order: $\mathrm{T} 3>\mathrm{T} 1>\mathrm{T} 2>\mathrm{C}(2468.75 \pm 13.1,2350.00 \pm 13.3,2300.00 \pm 13.4$ and $2011.87 \pm 20.6 \mathrm{~g} /$ rabbit respectively $)$. Both additives CM $3000^{\circledR}$ (T1) and Poultry-Star ${ }^{\mathbb{B}}$ (T2) significantly improved live body weight. The highest body weight was shown in rabbits fed on the mixture of CM3000 ${ }^{\circledR}$ and Poultry-Star ${ }^{\circledR}$ (T3) group. In the same way body weight gain showed significant differences at the end of the experiment in the following order: $\mathrm{T} 3>\mathrm{T} 1>$ $\mathrm{T} 2>$ control group.

Tables 4 and 5 show the feed consumed and feed conversion in the different groups. Rabbits reared on the diet containing mixture of CM3000® and Poultry-Star ${ }^{\circledR}$ (T3) consumed more feed than the control and the other treated groups. In addition, feed conversion was improved by the additives used to record 3.30 in T3 and T2 versus 3.53 in the control group. 
Table 4. Effects of sodium butyrate and/or synbiotic on feed intake of growing male rabbit (g/rabbit) raised to 70 days of age (means \pm SE)

\begin{tabular}{lllll}
\hline Age (day) & Control & $\begin{array}{l}\text { T1 } \\
\text { Sod. butyrate }\end{array}$ & $\begin{array}{l}\text { T2 } \\
\text { Synbiotic }\end{array}$ & $\begin{array}{l}\text { T3 } \\
\text { Mixture }\end{array}$ \\
\hline 49 & $381.06 \pm 16.8^{\mathrm{a}}$ & $381.10 \pm 15.5^{\mathrm{a}}$ & $381.06 \pm 12.3^{\mathrm{a}}$ & $377.57 \pm 11.6^{\mathrm{a}}$ \\
63 & $643.13 \pm 21.0^{\mathrm{a}}$ & $784.00 \pm 25.3^{\mathrm{c}}$ & $753.38 \pm 24.9^{\mathrm{b}}$ & $833.00 \pm 22.4^{\mathrm{d}}$ \\
77 & $1157.50 \pm 19.41^{\mathrm{a}}$ & $1298.50 \pm 27.2^{\mathrm{b}}$ & $1157.63 \pm 23.6^{\mathrm{a}}$ & $1350.56 \pm 21.7^{\mathrm{c}}$ \\
91 & $1359.75 \pm 28.9^{\mathrm{a}}$ & $1610.88 \pm 35.1^{\mathrm{c}}$ & $1537.38 \pm 33.6^{\mathrm{b}}$ & $1674.58 \pm 30.2^{\mathrm{c}}$ \\
105 & $1638.43 \pm 28.2^{\mathrm{a}}$ & $1990.00 \pm 25.3^{\mathrm{b}}$ & $1960.00 \pm 21.4^{\mathrm{b}}$ & $2140.68 \pm 20.5^{\mathrm{c}}$ \\
Total & $5179.87 \pm 20.6^{\mathrm{a}}$ & $6064.48 \pm 13.3^{\mathrm{c}}$ & $5789.45 \pm 13.4^{\mathrm{b}}$ & $6376.39 \pm 13.1^{\mathrm{d}}$ \\
\hline
\end{tabular}

Note. Different superscripts within a row indicate a significant treatment effect $(p<0.05)$.

Table 5. Effects of sodium butyrate and/or synbiotic on feed conversion (FCR) of growing male rabbit raised to 70 days of age (means \pm SE)

\begin{tabular}{lllll}
\hline Age (day) & Control & $\begin{array}{l}\text { T1 } \\
\text { Sod. butyrate }\end{array}$ & $\begin{array}{l}\text { T2 } \\
\text { Synbiotic }\end{array}$ & $\begin{array}{l}\text { T3 } \\
\text { Mixture }\end{array}$ \\
\hline 49 & 3.41 & 1.49 & 1.70 & 1.22 \\
63 & 2.94 & 1.49 & 1.83 & 1.58 \\
77 & 2.26 & 4.07 & 2.99 & 4.08 \\
91 & 4.78 & 4.16 & 3.56 & 3.52 \\
105 & 4.82 & 6.23 & 6.54 & 7.53 \\
Total & 3.53 & 3.36 & 3.30 & 3.30 \\
\hline
\end{tabular}

\subsection{Caecal Fermentation Parameters}

The results clearly demonstrate decrease in the $\mathrm{pH}$ in groups $\mathrm{T} 1$ and $\mathrm{T} 3$ compared to the control group $(p<0.05)$ (Table 6).

Table 6. Effects of sodium butyrate and/or synbiotic on caecal fermentation of growing male rabbit raised to70 days of age (means $\pm \mathrm{SE})$

\begin{tabular}{lllll}
\hline Parameter & Control & $\begin{array}{l}\text { T1 } \\
\text { Sod. butyrate }\end{array}$ & $\begin{array}{l}\text { T2 } \\
\text { Synbiotic }\end{array}$ & $\begin{array}{l}\text { T3 } \\
\text { Mixture }\end{array}$ \\
\hline $\mathrm{pH}$ & $6.79 \pm 0.12^{\mathrm{a}}$ & $6.32 \pm 0.03^{\mathrm{b}}$ & $6.92 \pm 0.07^{\mathrm{a}}$ & $6.29 \pm 0.03^{\mathrm{b}}$ \\
Ammonia & $17.35 \pm 1.11^{\mathrm{c}}$ & $14.58 \pm 0.96^{\mathrm{b}}$ & $17.32 \pm 0.33^{\mathrm{c}}$ & $13.87 \pm 0.81^{\mathrm{a}}$ \\
TVFA & $64.0 \pm 6.11^{\mathrm{a}}$ & $126.67 \pm 4.81^{\mathrm{a}}$ & $46.0 \pm 1.15^{\mathrm{a}}$ & $124.67 \pm 3.71^{\mathrm{a}}$ \\
Acetic acid mol\% & $55.17 \pm 0.93^{\mathrm{a}}$ & $58.56 \pm 1.96^{\mathrm{c}}$ & $62.35 \pm 0.22^{\mathrm{d}}$ & $56.98 \pm 1.82^{\mathrm{b}}$ \\
Propionic acid mole\% & $26.56 \pm 1.14^{\mathrm{c}}$ & $14.81 \pm 2.10^{\mathrm{a}}$ & $14.34 \pm 0.57^{\mathrm{a}}$ & $21.31 \pm 0.34^{\mathrm{b}}$ \\
butyric mol\% & $7.78 \pm 0.71^{\mathrm{a}}$ & $26.09 \pm 0.33^{\mathrm{c}}$ & $22.56 \pm 0.54^{\mathrm{b}}$ & $20.70 \pm 0.21^{\mathrm{b}}$ \\
\hline
\end{tabular}

Note. Different superscripts within a row indicate a significant treatment effect $(p<0.05)$.

Each treatment modified the VFAs profile within the caecum in a particular fashion. As for acetic acid proportion, the highest percent was recorded in $\mathrm{T} 2$ group compared to the $\mathrm{C}$ group, while all supplements lowered propionic acid molar proportion compared to C group. Regarding caecal NH3-N concentrations, both T1 and T3 groups demonstrated a decrease significantly $(p<0.05)$ with reference to control group. 


\subsection{Blood Parameters}

The results obtained from serum analyses are shown in table 7. An increase in the glucose concentration was reported in all treated groups and the highest was recorded in T3 group. Serum triglycerides showed highest values in the treated group (T1). Ammonia concentration recorded low values in T1 and T3 groups compared with the control one $(p<0.05)$.

Table 7. Effects of sodium butyrate and/or synbiotic on some blood parameters of growing male rabbit raised to70 days of age (means $\pm \mathrm{SE})$

\begin{tabular}{lllll}
\hline Parameter & Control & T1 & T2 & T3 \\
& & Sod. butyrate & Synbiotic & Mixture \\
\hline Albumin & $3.72 \pm 0.28^{\mathrm{a}}$ & $4.42 \pm 0.34^{\mathrm{b}}$ & $3.15 \pm 0.23^{\mathrm{a}}$ & $4.80 \pm 0.27^{\mathrm{c}}$ \\
Total protein & $6.04 \pm 0.20^{\mathrm{a}}$ & $6.25 \pm 0.28^{\mathrm{a}}$ & $5.67 \pm 0.40^{\mathrm{a}}$ & $6.53 \pm 0.38^{\mathrm{a}}$ \\
Urea & $35.14 \pm 4.27^{\mathrm{b}}$ & $30.61 \pm 3.75^{\mathrm{a}}$ & $63.29 \pm 5.18^{\mathrm{d}}$ & $37.49 \pm 4.60^{\mathrm{c}}$ \\
Triglycerides & $122.03 \pm 19.20^{\mathrm{b}}$ & $288.28 \pm 49.52^{\mathrm{c}}$ & $36.68 \pm 5.83^{\mathrm{a}}$ & $119.68 \pm 17.56^{\mathrm{b}}$ \\
Cholesterol & $127.03 \pm 20.27^{\mathrm{a}}$ & $96.73 \pm 13.72^{\mathrm{a}}$ & $109.00 \pm 9.70^{\mathrm{a}}$ & $81.38 \pm 12.67^{\mathrm{a}}$ \\
Glucose & $137.64 \pm 4.95^{\mathrm{a}}$ & $139.02 \pm 5.37^{\mathrm{b}}$ & $139.85 \pm 6.48^{\mathrm{b}}$ & $179.74 \pm 14.24^{\mathrm{c}}$
\end{tabular}

Note. Different superscripts within a row indicate a significant treatment effect $(p<0.05)$.

\subsection{Histological Investigation of the Intestinal Wall}

The effect of dietary treatments on the duodenal morphology (villus height, villus width and duodenal gland lenght) is shown in Table 8 and Figure 1. Dietary supplementations influenced the histomorphological measurements of duodenal villi and gland lenght comparing with the control. Feed additives increased significantly $(p<0.05)$ the villus and gland lengths in all treated groups when compared with the control. Furthermore, the mixture of sodium butyrate and synbiotic (T3) supplementation increased the gland lenght and villus width numerically compared with other additives.

Table 8. Effects of feed additive supplementations on the histomorphological parameters of the rabbit intestine (means \pm SE)

\begin{tabular}{lllll}
\hline Parameter & Control & $\begin{array}{l}\text { T1 } \\
\text { Sod. butyrate }\end{array}$ & $\begin{array}{l}\text { T2 } \\
\text { Symbiotic }\end{array}$ & $\begin{array}{l}\text { T3 } \\
\text { Mixture }\end{array}$ \\
\hline Villus height $(\mu \mathrm{m})$ & $349 \pm 11^{\mathrm{a}}$ & $395 \pm 12^{\mathrm{b}}$ & $378 \pm 12^{\mathrm{b}}$ & $389 \pm 13^{\mathrm{b}}$ \\
Villus width $(\mu \mathrm{m})$ & $43 \pm 1.4^{\mathrm{a}}$ & $44 \pm 1.9^{\mathrm{ab}}$ & $49 \pm 2.3^{\mathrm{bc}}$ & $51 \pm 1.7^{\mathrm{c}}$ \\
Gland lenght $(\mu \mathrm{m})$ & $177 \pm 10^{\mathrm{a}}$ & $250 \pm 20^{\mathrm{b}}$ & $236 \pm 14^{\mathrm{b}}$ & $286 \pm 19^{\mathrm{b}}$ \\
\hline
\end{tabular}

Note. Different superscripts within a row indicate a significant treatment effect $(p<0.05)$. 

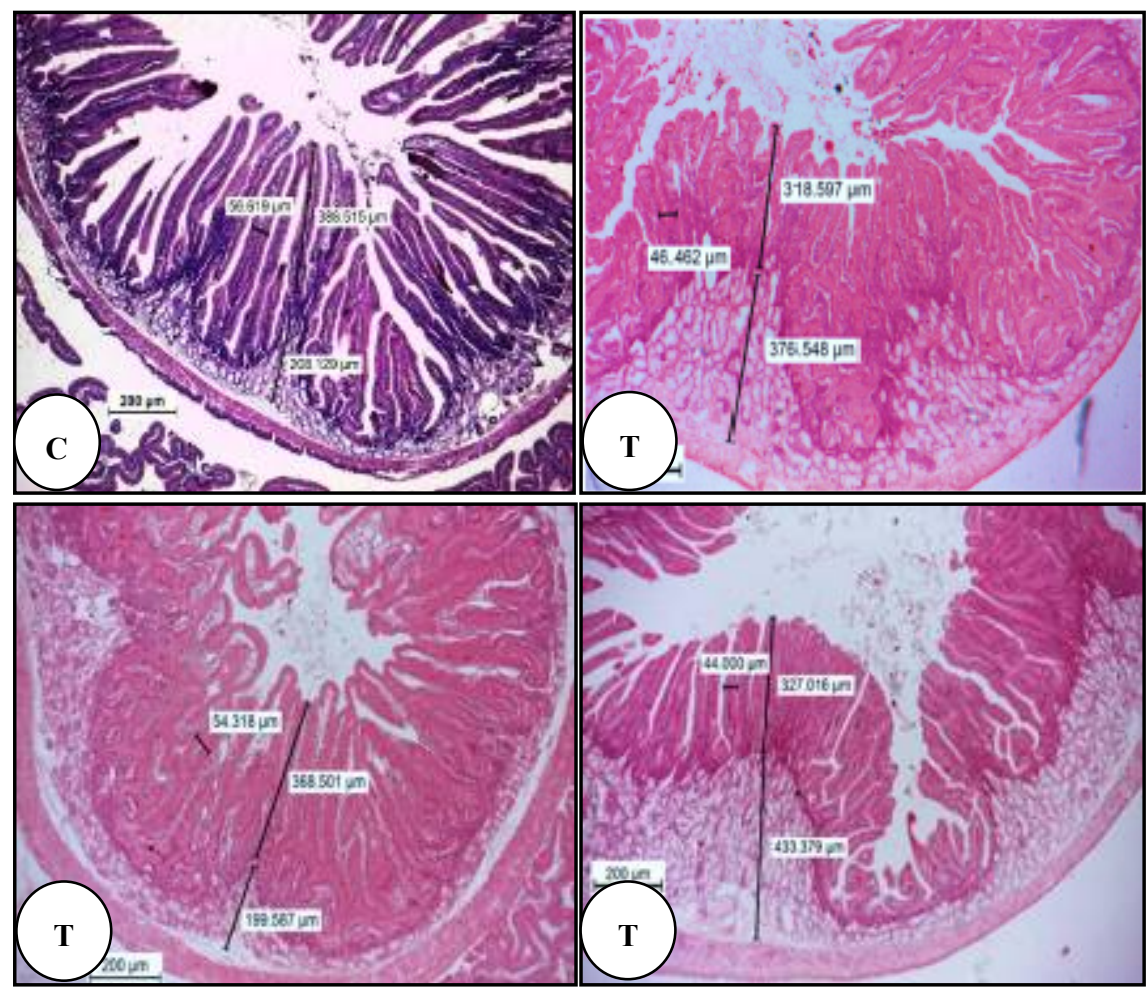

Figure 1. Photomicrographs of the small intestine (duodenum) from male New Zealand white rabbits showing the intestinal villi and duodenal glands. (C) Control group; (T1) Sodium butyrate supplemented group; (T2) Symbiotic supplemented group; (T3) Mixture of butyrate and symbiotic group, (H\&E) staining

\section{Discussion}

From the obtained results it is clear that rabbits performance was enhanced by the additive used. These findings can be explained in the light of that short chain fatty acids (SCFA) produced by microbial fermentation from dietary fibre stimulate epithelial cell proliferation resulting in a larger absorptive surface (Sakata, 1988; Leeson et al., 2005; Hu \& Guo, 2007; Panda et al., 2009). Moreover, normal colonic epithelia derive 60 to $70 \%$ of their energy supply from SCFA, particularly from butyric acid (Scheppach et al., 1992). Butyric acid induces cell differentiation and regulates the growth and the proliferation of normal colonic mucosa (Treem et al., 1994) while suppressing the growth of cancer cells (Clausen et al., 1991). Synbiotic products contain viable bacterial cultures that establish early in the gut while the prebiotic present in them serve as a source of nutrients for the probiotics in addition to dietary sources (Mohnl et al., 2007; Zhang et al., 2006). Probiotics and/or synbiotics could have positive effects on bacterial population in the gastrointestinal tract (Smirnov et al., 2005), and the addition of probiotic to diets has been found to improve growth performance (Jin et al., 1997; Wenk, 2000). Gut microflora changes actively by adding prebiotics and significantly reduces gut $\mathrm{pH}$ which improve rabbit's performance through influencing gut microbial population (Rahmani \& Speer, 2005). Hooge (2004) reported that positive effects of mannan oligosaccharides on animal performance could be more visible during stressful, high temperature as that situation in Egypt, high density and weak management conditions. Prebiotics are potential alimentary supplements which reduce harmful effects of putrefactive factors and increases nutrition output (Fooks \& Gibson, 2002). Also it has been reported that using prebiotics increases nutrient absorbance area via increasing gut length and thus improves bird performance (Santin et al., 2001). In the present study butyrate and synbiotic mixture used affected the productive performance of rabbits synergistically and revealed positive results on rabbit growth and zootechnical performance.

The obtained results of feed conversion reflect the efficient utilization of feed by the additives used. These results coincide with Tony et al. (2014), who concluded that coated and slowly released sodium butyrate $\left(\mathrm{CM} 3000^{\circledR}\right)$ could significantly improve broiler performance and feed conversion. They mentioned that the oral administration of $\mathrm{CM} 3000^{\circledR}$ enhances resistance to Salmonella Enteritidis challenge and markedly reduce Salmonella shedding. In the present study butyrate and synbiotic mixture used affected the productive performance of rabbits synergistically and revealed positive results on rabbit growth and zootechnical 
performance.

The analyses of caecal contents revealed significant decrease in the $\mathrm{pH}$ in $\mathrm{T} 1$ and $\mathrm{T} 3$ compared with $\mathrm{C}$ group. This observation may be due to an increase in TVFA concentration reported in former groups. These short-chain carboxylic acids in the gastrointestinal tract of non-ruminants reflect the amount consumed and the rate of intraluminal production by anaerobic microorganisms from fermentable substrate (Smulikowska et al., 2009). These acids have a number of important regulatory functions related to gastrointestinal functionality, among others mucosal development, proliferation, differentiation, maturation and apoptosis of enterocytes and colonocytes (Mroz et al., 2006).

Propionic acid is a valuable substrate in glucose synthesis in many species (Bergman, 1990) as it contributes in gluconeogenesis and formation of long-chain fatty acids in the liver and its intermediate products change and participate in regulation of a series of processes, including ketogenesis, gluconeogenesis and ureogenesis (Remesy et al., 1995). Despite lower propionic acid molar proportion, the present study failed to demonstrate a decrease in serum glucose concentration in the experimental groups, but rather an increase in the glucose concentration was reported in T3 group which may be due to better digestibility and absorption of carbohydrates, secondary to the improvement in intestinal morphometry. Concerning butyrate, all experimental groups showed higher concentrations compared to $\mathrm{C}$ group with highest \% recorded for $\mathrm{T} 1$ group. As butyrate is an essential precursor in lipogenesis (Remesy et al., 1995), serum triglycerides showed highest values in the former group (T1). Moreover, butyrate is recognized as the most effective source of energy for epithelial cells proliferation (Mroz et al., 2006), where sodium butyrate has been reported to be helpful in maintenance of intestinal villi structure after coccidial challenge (Leeson et al., 2005).

According to Macfarlane and Gibson (1995) a series of factors could influence NH3-N concentrations within the caecum, including $\mathrm{H} 2$ pressure, chyme reaction, and carbohydrates availability. In comparison with ruminants, proteolytic activity in the rabbit caecum is relatively higher (Gidenne, 1997). The lower recorded ammonia concentration in T1 and T3 group could be attributed to either increased nitrogen retention by enterocytes and colonocytes in these groups which may be connected with greater epithelial cell proliferation in gastrointestinal tract as suggested by Smulikowska et al. (2009) or better ammonia utilization in liver for protein production, this seems true since albumen concentrations were increased in $\mathrm{T} 1$ and $\mathrm{T} 3$ groups. The decreased in caecal $\mathrm{pH}$, the decreased in ammonia-N concentration and the higher VFA concentration suggest high fermentation activity, caecal microbial synthesis, gut health and high nitrogen retention. This observation is consistent with the growth performance result discussed above, and is also in agreement with the results of Garcia et al. (2000).

Concerning serum total proteins all supplements did not alter serum values reflecting that the experimental animals were in a good nutritional status and liver has no pathological lesions (Abdl-Rahman et al., 2010).

The histomorphological changes in the intestine of growing rabbit reported in the present study provide new information regarding the potential for using synbiotics and probiotics in rabbit feed. Increasing the villus height suggests an increased surface area capable of greater absorption of available nutrients (Caspary, 1992). Feeding of probiotics has been shown to induce gut epithelial cell proliferation in rats (Ichikawa et al., 1999). The intestinal epithelial cells originating in the crypt migrate along the villus surface upward to the villus tip and are extruded into the intestinal lumen within 48 to $96 \mathrm{~h}$ (Imondi and Bird, 1966; Potten, 1998). A shortening of the villi may lead to poor nutrient absorption, increased secretion in the gastrointestinal tract, and lower performance (Xu et al., 2003). In contrast, increases in the villus height and villus height:crypt depth ratio are directly correlated with increased epithelial cell turnover (Fan et al., 1997). It is understood that greater villus height is an indicator that the function of intestinal villi is activated (Langhout et al., 1999; Shamoto \& Yamauchi, 2000). This fact suggests that the villus function is activated after feeding of dietary probiotic and synbiotic.

In the present study, coated sodium butyrate supplementation was associated with increased intestinal morphological parameters compared with the control (Table 8 and Figure 1). Sodium butyrate has been reported to be helpful in maintenance of intestinal villi structure after coccidial challenge (Leeson et al., 2005). Moreover, Mroz et al. (2006) reported that butyrate is recognized as the most effective source of energy for epithelial cells proliferation. Per contrary, in pigs and chickens, the effect of sodium butyrate on small intestinal epithelium is often insignificant (Biagi et al., 2007; Hu \& Guo, 2007).

\section{Conclusion}

Exogenous administration of coated, slow-release butyrate $\left(\mathrm{CM} 3000^{\circledR}\right)$ combined with synbiotic (Poultry-Star $\left.{ }^{\circledR}\right)$ is capable of improving zootechnical performance, enhancing intestinal health. Butyrate with synbiotic mixture may be used as alternatives for antibiotics in rabbit nutrition to improve growth performance that would be a valuable feeding strategy in developing countries. 


\section{Acknowledgements}

The authors thank Hangzhou King Techina Feed Co., Ltd, China, Ms. Shuyi Li and Dr. Tony Niu for supplying of $\mathrm{CM} 3000^{\circledR}$ used in the study and for their support. The authors also thank BIOMIN America, Inc, USA for supplying of Poultry-Star ${ }^{\circledR}$.

\section{References}

Abdl-Rahman, M. A., Sawiress, F. A. R., \& Sohair, Y. S. (2010). Effect of Kemzyme-Bentonite Co-supplementation on Cecal Fermentation and Metabolic Pattern in Rabbit. Journal of Agicultural Science, 2, 183-188.

Allain, C. C., Poon, L. S., Chan, C. S. G., Richmond, W., \& Fu, P. C. (1974). Enzymatic determination of total serum cholesterol. Clin Chem, 20, 470.

AOAC. (1999). Official Methods of Analysis. Association of Official Analytical Chemists, Washington DC.

Bergman, E. N. (1990). Energy contributions of volatile fatty acids from the gastrointestinal tract in various species. Physiological Reviews, 2, 567-590.

Biagi, G., Piva, A., Moschini, M., Vezzali, E., \& Roth, F. X. (2007). Performance, intestinal microflora, and wall morphology of weanling pigs fed sodium butyrate. J. Anim. Sci., 85, 1184-1191. http://dx.doi.org/10.2527/jas.2006-378

Bron, F., Kettlitz, B., \& Arrigoni, E. (2002). Resistant starches and the butyrate revolution. Trends Food Sci. Technol., 13, 251-261. http://dx.doi.org/10.1016/S0924-2244(02)00131-0

Caspary, W. F. (1992). Physiology and pathophysiology of intestinal absorption. Am. J. Clin. Nutr., 55, 299S-308S.

Chaney, A. L., \& Marbach, E. P. (1962). Modified reagents for determination of urea and ammonia. Clinical Chemistry, 8, 130-132.

Clausen, M. R., Bonnen, H., \& Mortensen, P. B. (1991). Colonic fermentation of dietary fibre to short chain fatty acids in patients with adenomatous polyps and colonic cancer. Gut, 32,923-928. http://dx.doi.org/10.1136/gut.32.8.923

Collier, C. T., Carroll, J. A., Ballou, M. A., Starkey, J. D., \& Sparks, J. C. (2010). Oral administration of Saccharomyces cerevisiaeboulardii reduces mortality associated with immune and cortisol responses to Escherichia coli endotoxin in pigs. Journal of Animal Science, 89, 52-58. http://dx.doi.org/10.2527/jas.2010-2944

Corcionivoschi, N., Drinceanu, D., Mircea, P. I., Stack, D., Ştef, L., Julean, C., \& Bourke, B. (2010). The effect of probiotics on animal health. Animal Science and Biotechnologies, 43, 35-41.

Dalle Zotte, A. (2000). Main factors influencing the rabbit carcass and meat quality. Proc. 7th World Rabbit Congress (Vol. A-B, pp. 507-537). Valencia, Spain.

Eadie, J. M., Hobson, P. N., \& Mann, S. O. (1967). A note on some comparisons between the rumen content of barley fed steers and that of young calves also fed on high concentrate rations. Animal production, 9, 247-250. http://dx.doi.org/10.1017/S0003356100038514

European Commission. (2003). Opinion on the use of certain micro-organisms as additives in feedingstuffs. Report prepared for Health \& Consumer Protection Directorate-General.

Ewing, W. N. (2008). The living gut (p. 192). Nottingham, UK: Nottingham University Press.

Fan, Y., J. Croom, V., Christensen, B., Black, A., Bird, L., Daniel, B., ... Eisen, E. (1997). Jejunal glucose uptake and oxygen consumption in turkey poults selected for rapid growth. Poult. Sci., 76, 1738-1745. http://dx.doi.org/10.1093/ps/76.12.1738

Fawcett, J. K., \& Scott, J. E. (1960). A rapid and precise method for the determination of urea. J. Clin. Pathol., 13,156-159. http://dx.doi.org/10.1136/jcp.13.2.156

Fooks, L. J., \& Gibson, G. R. (2002). Probiotics as modulators of the gut flora. British Journal Nutrition, 88, 39-49. http://dx.doi.org/10.1079/BJN2002628

Garcia, J., Carabano, R., Perez-Alba, L., \& de Blas, J. C. (2000). Effect of fiber source on cecal fermentation and nitrogen recycled through cecotrophy in rabbits. J. Anim. Sci., 78, 638-646.

Gidenne, T. (1997). Caeco-colic digestion in the growing rabbit: impact of nutritional factors and related 
disturbances. Livestock Production Science, 51, 73-88. http://dx.doi.org/10.1016/S0301-6226(97)00111-5

Henry, R. J. (1964). Colorimetric determination of total protein. Clinical Chemistry (p. 181). Harper and Row Publ., New York, USA.

Hooge, D. (2004). Meta-analysis of broiler chicken pen trials evaluating dietary mannan oligosaccharide, 1993-2003. International Journal of Poultry Science, 3, 163-174. http://dx.doi.org/10.3923/ijps.2004.163.174

Hu, Z., \& Guo, Y. (2007). Effects of dietary sodium butyrate supplementation on the intestinal morphological structure, absoptive function and gut flora in chickens. Aniemal Feed Science and Technology, 132, 240-249. http://dx.doi.org/10.1016/j.anifeedsci.2006.03.017

Hume, M. E., Corrier, D. E., Ivie, G. W., \& Deloach, J. R. (1993). Metabolism of [14C] propionic acid in broiler chicks. Poult. Sci., 72, 786-793. http://dx.doi.org/10.3382/ps.0720786

Ichikawa, H., Kuroiwa, T., \& Inagaki, A. (1999). Probiotic bacteria stimulate epithelial cell proliferation in rat. Dig. Dis. Sci., 44, 2119-2123. http://dx.doi.org/10.1023/A:1026647024077

Imondi, A. R., \& Bird, F. H. (1966). The turnover of intestinal epithelium in the chick. Poult. Sci., 45, 142-147. http://dx.doi.org/10.3382/ps.0450142

Jin, L. Z., Ho, Y. W., Abdullah, N., \& Jalaludin, S. (1997). Probiotic in poultry: Modes of action. World's Poult. Sci. J., 53, 351-368. http://dx.doi.org/10.1079/WPS19970028

Langhout, D. J., Schutte, J. B., Van, L. P., Wiebenga, J., \& Tamminga, S. (1999). Effect of dietary high and low methylated citrus pectin on the activity of the ileal microflora and morphology of the small intestinal wall of broiler chickens. Br. Poult. Sci., 40, 340-347. http://dx.doi.org/10.1080/00071669987421

Leeson, S., Namkung, H., Antongiovanni, M., \& Lee, E. H. (2005). Effect of butyric acid on the performance and carcass yield of broiler chickens. Poult. Sci., 84, 1418-1422. http://dx.doi.org/10.1093/ps/84.9.1418

Macfarlane, G. T., \& Gibson, G. R. (1995). Microbiological aspects of the production of short-chain fatty acids in the large bowel. In J. H. Cummings, J. L. Rombeau \& T. Sakata (Eds.), Physiological and Clinical Aspects of Short-chain fatty acids (pp. 87-105). Cambridge Univ Press, London.

Mohnl, M., Acosta Aragon, Y., Acosta Ojeda, A., Rodriguez Sanchez, B., \& Pasteiner, S. (2007). Effect of synbiotic feed additive in comparison to antibiotic growth promoter on performance and health status of broilers. Poult. Sci., 86(Suppl. 1), 217.

Mroz, Z., Koopmans, S. J., Bannink, A., Partanen, K., Krasucki, W., Øverland, M., \& Radcliffe, S. (2006). Carboxylic acids as bioregulators and gut growth promoters in nonruminants. In R. Mosenthin, J. Zentek, T. Żebrowska (Eds.), Biology of Nutrition in Growing Animals (pp. 81-133). Elsevier, Edinburgh, UK. http://dx.doi.org/10.1016/S1877-1823(09)70091-8

NRC. (1977). Nutrient requirements of rabbits( 2nd ed.). National Academy of Sciences. Washington, DC.

Panda, A. K., Rama Rao, S. V., Raju, M. V. L. N., \& Shyam Sunder, G. (2009). Effect of Butyric Acid on Performance, Gastrointestinal Tract Health and Carcass Characteristics in Broiler Chickens. Asian-Aust. J. Anim. Sci., 22, 1026-1031.

Peret, F. L. A., Penna, F. J., Bambirra, E. A., \& Nicoll, J. R. (1998). Dose effect of oral Saccharomyces boulardii treatments on morbidity and mortality in immunosuppressed mice. Journal of Medical Microbiology, 47, 111-116. http://dx.doi.org/10.1099/00222615-47-2-111

Potten, C. S. (1998). Stem cells in the gastrointestinal epithelium: Numbers, characteristics and death. Philos. Trans. R. Soc. Lond. B. Biol. Sci., 353, 821-830. http://dx.doi.org/10.1098/rstb.1998.0246

Rahmani, H. R., \& Speer, W. (2005). Natural additives influence the performance and humoral immunity of broilers. International Journal of Poultry Science, 4, 713-717. http://dx.doi.org/10.3923/ijps.2005.713.717

Remesy, C., Demigne, C., \& Morand, C. (1995). Metabolism of short-chain fatty acids in the liver. In J. H. Cummings, J. L. Rombeau, \& T. Sakata (Eds.), Physiological and Clinical Aspects of Short-chain fatty acids (pp. 171-190). Cambridge University Press, London.

Sakata, T. (1987). Stimulatory effect of short-chain fatty acids on epithelial cell proliferation in the rat intestine: a possible explanation for tropic effects of fermentable fibre, gut microbes and luminal tropic factors. $\mathrm{Br} . \mathrm{J}$. Nutr., 58, 95-103. http://dx.doi.org/10.1079/BJN19870073

Sakata, T. (1988). Chemical and physical trophic effects of dietary fibre on the intestine of monogastrics animals. 
In L. Buraczewska, S. Buraczewski, B. Pastuszewska, T. Zebrowska (Eds.), Digestive Physiology in the pig (pp. 128-135). Polish Academy of Science, Joblonna, Poland.

Samuel, M., Sagathewan, S., Thomas, J., \& Mathen, G. (1997). An HPLC method for estimation of volatile fatty acids of ruminal fluid. Indian J. Anim. Sci., 67, 805-807.

Santin, E., Maiorka, A., Macari, M., Grecco, M., Sanchez, J. C., Okada, T. M., \& Myasaka, A. M. (2001). Performance and intestinal mucosa development of broiler chickens fed diet containing Sccharomyces cerevisiae cell wall. Journal of Applied Poultry Research, 10, $236-244$. http://dx.doi.org/10.1093/japr/10.3.236

Scheppach, W., H., Sommer, T., Kirchner, G. M., Paganelli, P., Bartram, S., Christl, F., ... Kasper, H. (1992). Effect of butyrate enemas on the colonic mucosa in distal ulcerative colitis. Gastroenterology, 103(1), 51-56.

Shamoto, K., \& Yamauchi, K. (2000). Recovery responses of chick intestinal villus morphology to different refeeding procedures. Poult. Sci., 79, 718-723. http://dx.doi.org/10.1093/ps/79.5.718

Sharma, R., Schumarcher, U., Ronaasen, V., \& Coates, M. (1995). Rat intestinal mucosal responses to a microbial flora and different diets. Gut., 36, 206-214. http://dx.doi.org/10.1136/gut.36.2.209

Smirnov, A., Perez, R., Amit-Romach, E., Sklan, D., \& Uni, Z. (2005). Mucin dynamics and microbial populations in chicken small intestine are changed by dietary probiotic and antibiotic growth promoter supplementation. J. Nutr., 135, 187-192.

Smulikowska, S., Czerwiński, J., Mieczkowska, A., \& Jankowiak, J. (2009). The effect of fat-coated organic acid salts and a feed enzyme on growth performance, nutrient utilization, microflora activity, and morphology of the small intestine in broiler chickens. Journal of Animal and Feed Sciences, 18, 478-489.

Snedecor, F. W., \& Cochran, W. G. (1980). Statistical methods 7th ed. Lowa State Univ. Press Ames .I.A.

Sunkara, L. T., Achanta, M., Schreiber, N. B., Bommineni, Y. R., Dai, G., Jiang, W., ... Zhang, G. (2011). Butyrate enhances disease resistance of chickens by inducing antimicrobial host defense peptide gene expression. PLoS One, 6, e27225. http://dx.doi.org/10.1371/journal.pone.0027225

Tony, M. A., Hamoud, M. M., Bailey, C. A., \& Hafez, H. M. (2014). Effects of coated sodium butyrate $(\mathrm{CM} 3000 \AA)$ as a feed additive on zootechnical performance, immune status and Salmonella Enteritidis shedding after experimental infection of broiler chickens. Proceeding of Poultry Science Association meeting. Corpus Christi, Texas, USA.

Treem, W. R., Ahsan, N., Shoup, M., \& Hyams, J. S. (1994). Fecal short-chain fatty acids in children with inflammatory bowel disease. J. Pediatr. Gastroenterol. Nutr., 18(2), 159-164. http://dx.doi.org/10.1097/00005176-199402000-00007

Trinder, P. (1969). Determination of glucose in blood using glucose oxidase with an alternative oxygen acceptor. Ann. Clin Biochem., 6, 24. http://dx.doi.org/10.1177/000456326900600108

Van der wielen, P. (2000). Dietary strategies to influence the gastrointestinal microflora of young animals and its potential to improve intestinal health. Nutrition and Health of the Gastrointestinal Tract (pp. 37-60). M.C. Blok, H.A.

Wenk, C. (2000). Recent advances in animal feed additives such as metabolic modifier, antimicrobial agents, probiotics, enzymes and available minerals. Asian-Aust. J. Anim. Sci., 13, 86-95. http://dx.doi.org/10.5713/ajas.2000.86

Xu, Z. R., Hu, C. H., Xia, M. S., Zhan, X. A., \& Wang, M. Q. (2003). Effects of dietary fructooligosaccharide on digestive enzyme activities, intestinal microflora and morphology of male broilers. Poult. Sci., 82, 1030-1036. http://dx.doi.org/10.1093/ps/82.6.1030

Zhang, G., Ma, L., \& Doyle, M. P. (2006). Effect of Probiotics, Prebiotics and Symbiotics on Weight Increase of Chickens (Gallus domesticus). Retrieved from http//www.ugacfs.org/research/pdf/poultry 2006.pdf

\section{Copyrights}

Copyright for this article is retained by the author(s), with first publication rights granted to the journal.

This is an open-access article distributed under the terms and conditions of the Creative Commons Attribution license (http://creativecommons.org/licenses/by/3.0/). 